Bolm Inst. oceanogr. S Paulo, 20 (2): 71-78, 1971

\title{
NOTES ON THE BULL SHARK CARCHARHINUS LEUCAS IN THE LAGOON REGION OF CANANEIA, BRAZIL
}

(Received 5/6/1971)

V. SADOWSKY

Instituto oceanogräfico da Universidade de são Pauzo

\section{SYNOPSIS}

Ninety one young specimens and 3 adult females of Bull shark ("cação cabeça chata") caught in the lagoon region of Cananéia were examined, their tooth formula being $27 / 25$ and the number of pre-caudal vertebrae ranging from 109 to 115. The proportion between the 1 st and 2 nd dorsal fins were found to be 2.3 and 2.8 for the young, and 2.9 to 3.1 for the adults. These data confirm that the studied form belongs to $C$. Zeucas. Young occur regularly but in limited numbers. As regards the adults, however, females only appear during the short parturition period, i.e., from November to February. The number of embryos in the litters were from 7 to 9, their sizes ranging between $768-812 \mathrm{~mm}$. The length of the smallest free young found was $697 \mathrm{~mm}$, but young presumably 9 to 12 months old had 98 to $112 \mathrm{~cm}$; between 21 and 24 months they were reaching 124 to $128 \mathrm{~cm}$, that is, the same size they have when they start migrating to the open sea. The feeding inhibition phenomenon during the period of parturition was not observed in the female specimens caught in the 1 agoon.

The more abundant species found in the stomach contents were: Arius spixii; Chloroscombrus chrysurus; A. grandicassus; A. barbus; Felichtys marinus; Genidens genidens; Chanophorus tajacica and Carcharhinus porosus.

\section{INTRODUCTION}

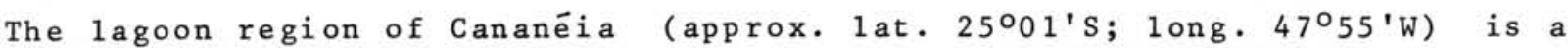
system of interlinked canals and lagoons, distributed along the southern coast of the State of São Paulo for more than $110 \mathrm{~km}$, and situated on the West Atlantic limits of the range of the Bull shark, Carcharhinus Zeucas (Valenciennes in Müller \& Henle, 1841).

The occurrence of this species has not been recorded in the southernmost Brazilian waters (Jakobi \& Souza, 1968; Barce11os, 1962; Lema, 1963), nor in Uruguay (Ximenex, 1962) its center of abundance is found, according to Baughman \& Springer (1950, p. 108) in the West Indies-Caribbean. 
Therefore, C. Zeucas, known locally as "cação cabeça chata", is not common in these waters (Sadowsky, 1967) and is caught in 1 imited numbers of 40 to 60 specimens per year. Inside the lagoon region young sharks are caught, with sizes ranging between 69 to $128 \mathrm{~cm}$, and occasionally females, gravid or showing signs of recent parturition, during the procreation period. In inshore waters young or sub-adults are caught in sizes varying between 130 to $170 \mathrm{~cm}$, as we 11 as a few adult specimens of both sexes.During spring and summer seasons Bul1 sharks occur more frequently.

The area of procreation of C. Zeucas comprises a relatively large part of the lagoon system, about $18 \mathrm{~km}$ in length and $2 \mathrm{~km}$ wide, called "baía do Trapandé" and "baía do Cubatão", located to the south of the Is land of Cananéia and belonging to a region whose topography, hydrographic regime, ecology, as we 11 as flora and fauna,have already been studied in several papers published in the "Boletim" and "Contribuições Avulsas" of the Instituto Oceanogräfico (from 1951 to 1969), or abroad (Gerlach, 1958).

\section{MATERIAL AND METHODS}

The material used in this study was collected in the lagoon region, during the years 1966-1969. For the capture of the specimens gill nets and set 1 ines were used. The sharks were identified and measured in fresh state, according to the recommendations of Bigelow \& Schroeder (1948), Sadowsky (1968), and others. The vertebrae were counted after removal of the muscles of the vertebral column. The term "pre-caudal vertebrae" is used in the sense of springer \& Garrick (1964). The size of the sharks is presented as total length. The fish remains in the stomach contents were identified by comparing the type and size of otoliths found in the specimens with those of a collection existing in the local Research Station.

\section{RESULTS}

A total of 91 young specimens and three adult females were caught and examined. The morphometric data gathered are consistent with great approximation with those presented previously by several authors, referring to $C$. Zeucas: Bigelow \& Schroeder (1948, p. 339); Schwartz (1961, p. 69); Fourmanoir (1961, p. 16); Clark \& Schmidt (1965, p. 69); Thorson, Cowan \& Watson (1966, p. 621). The number of teeth in the dental formula was found very stable being 13-1-13 for the upper and 12-1-12 for the lower teeth. For the upper teeth on $1 \mathrm{y}$ in 6 cases a variation of an extra tooth was found and, conversely,the number of the lower teeth was 24 , however, in a single case, 23 were found.

In the 27 specimens examined for their vertebrae, the number of pre-caudal vertebrae varied from 109 to 115 , the average being 113. Also the complementary examination of the vertebrae of a female and its 9 fetuses showed that the variation is not significant, viz.: female - 112; fetuses - from 110 to 113 , 
the total number of vertebrae ranging between 119 to 124 . One adult female had two double vertebrae completely fused together. In said specimen the measurements of the length of the vertebrae were: $22 \mathrm{nd}-15.1 \mathrm{~mm} ; 23 \mathrm{rd}+24 \mathrm{th}$ $29.2 \mathrm{~mm} ; 25 \mathrm{th}-15.3 \mathrm{~mm} ; 32 \mathrm{nd}-15.2 \mathrm{~mm} ; 33 \mathrm{rd}+34 \mathrm{th}-28.1 \mathrm{~mm} ; 35 \mathrm{th}-15.9 \mathrm{~mm}$.

The adult females were caught by means of a set line baited with "carape bas", Diapterus rhombeus (Cuvier), $20-30 \mathrm{~cm} 1$ ong, in depths of 4 to $6 \mathrm{~m}$, on muddy bottom, water temperature at the surface at the time of fishing, 25.80 and $26.3^{\circ} \mathrm{C}$. The salinity was, respective $1 \mathrm{y}, 230 / 00$ and $16^{\circ} / 00$.

TABLE I - Data on adult females caught in the lagoon region of Cananéia

\begin{tabular}{cccccccc}
\hline No. & Date & $\begin{array}{c}\text { T.L. } \\
(\mathrm{cm})\end{array}$ & $\begin{array}{l}\text { Stomach } \\
\text { contents }\end{array}$ & $\begin{array}{l}\text { No. in } \\
\text { 1itter }\end{array}$ & $\begin{array}{c}\text { Sizes of } \\
\text { fetuses }(\mathrm{cm})\end{array}$ & $\begin{array}{c}\text { Sexus of } \\
\text { fetuses }\end{array}$ \\
\hline 1 & $02 / 12 / 1966$ & 275.5 & fish & 7 & $79.2-81.2$ & 50 & 29 \\
2 & $16 / 12 / 1969$ & 272.0 & fish & 9 & $76.8-80.7$ & 40 & 29 \\
3 & $16 / 12 / 1969$ & 260.5 & fish & (showing signs of recent parturition)
\end{tabular}

The young sharks were caught in the same area. The catches are distributed by months in Table II, being conditioned by the abundance of fish, hydrographic and weather conditions, as well as by the efficiency of the gear used in the fishery. Notwithstanding the fragmentary nature of the gathered data, the set of records gives us a general outlook on some aspects of the biology of this species (Table II).

It was possible to conclude that the period of parturition 1 asts about 4 months, from November to February, when the females caught were in the 1 ast stages of pregnancy, or immediately after parturition.Young of small size were also captured then, equivalent to the fetuses found, with pseudo-placenta orifices open or half open. Corresponding to the months of the referred period the tabulated data form three groups: 1 - the probably new-born generation with sizes not exceeding $82,84,88$ and $90 \mathrm{~cm}$, in four consecutives months; 2- the evidently yearlings with sizes respectively between 98-112,100-112,112-(120?) and 108-118; and 3- the probab1y two-year old sharks, 124-128, 00-00, 00-00 (120?) and $128 \mathrm{~cm}$ long. In the following months the components of these groups gradua11y increase in size until they reach, in october - group 1- from 98 to $108 \mathrm{~cm} ; 2$ - a minimum of $122 \mathrm{~cm}$. For group 3 there are no records available in this period, as they disappear completely. This might be explained by the emigration of these larger specimens, when they reach 128-130 cm, into coastal waters of the open sea where they are frequently fished by local fis hermen.

The examination of the stomach contents showed that $66 \%$ of a total of 94 specimens had empty stomachs. The following species of fish were identified in Bolm Inst. oceanogr. S Paulo, 20 (2): 71-78, 1971 
$42 \mathrm{~cm}$ maximum width; Carcharhinus porosus, of $101 \mathrm{~cm}$ and Diapterus rhombeus, $31 \mathrm{~cm}$; Carcharhinus porosus, of ca. 60-70 cm, and fish remains (otoliths of Micropogon furnieri, of ca. 40-50 cm); Dasyatis americana, of $60 \mathrm{~cm}$ maximum width. The young stomachs contained: Sphyrna tiburo, of ca. 50-56 cm; Chloroscombrus chrysurus, 7 specimens of $10-15 \mathrm{~cm}$; Arius spixii, 13 specimens of 10$18 \mathrm{~cm}$; Arius grandicassus, 6 specimens of 15-21 cm; A. barbus, 4 specimens of 28-39 cm; Felichtys marinus, 3 specimens of 17-22 cm; Genidens genidens, 2 specimens of 23-25 cm; Chanophorus tajacica, 1 specimen of $36 \mathrm{~cm}$; Conodon nobilis, 1 specimen of $18 \mathrm{~cm}$; Caranx crysos, 1 specimen of $36 \mathrm{~cm}$; Scomberomorus maculatus, 1 specimen of $42 \mathrm{~cm}$ and several remains of "siri" Callinectes sp. (ca. 25-30 specimens).

It must be pointed out that although species of the genus spheroides are abundant in the lagoon region, not a single specimen of this genus was found in the stomachs of the Bull sharks examined. This is still more remarkable considering that these fishes are not rejected by other species of sharks, they are commonly found in the stomachs of Carcharhinus maculipinnis (Poey) and Galeocerdo cuvieri(Peron \& LeSueur), which are fished near the bar of Cananeia.

\section{DISCUSSION}

During the research, litters of 7 to 9 fetuses were found, this number is equal to that cited in the literature (Clark \& Schmidt, 1965, p, 28), However, the respective lengths of the present fetuses (from 768 to $807 \mathrm{~mm}$ and from 792 to $812 \mathrm{~mm}$ ) are markedly larger than the measures mentioned by several authors, as the normal size of the young at birth. Bigelow \& Schroeder (1948, p. 341) mention 650 to $700 \mathrm{~mm}$; C1ark \& Schmidt (1965, p, 29) give 740 to $750 \mathrm{~mm}$, but point out that some individuals may be a 1ittle larger at birth; D'Aubrey (1964, p. 40) says that they are born with a little over 24 inches (610 mm); Springer (1940, p. 190; 1960, p. 11) mentions approximately 710 $\mathrm{mm}$; Fourmanoir (1961, p. 39; 1965 , p. 10) indicates that the young at birth measure from 600 to $700 \mathrm{~mm}$, but in his next paper he gives an account of the finding of a litter with 6 embryos having $700 \mathrm{~mm}$; finally Thorson, Cowan \& Watson (1966, p. 620) report the catch of young ranging between 694 to $701 \mathrm{~mm}$.

Since the simultaneous occurrence of young with lengths between 697 and $820 \mathrm{~mm}$ has been stated in Cananeia, during November, it is evident that the variation of maximum size of the fetuses must suffer remarkable fluctuations, so that it is assumed that there may be some correlation between the size of the new-born and the length of the female which gave birth to them, or even with her physical conditions, considering that the females examined were exceptionally large. In respect to the possible correlation existing between the pregnant females and the number of embryos in the litter a few observations have already been made by Backus, Springer \& Arnold (1956, p. 18). 
As regards the growth rate of Bull sharks (Table II) it is evident that the young of ca. 9 to 12 months old measure from 98 to $112 \mathrm{~cm}$, reaching sizes of 124 to $128 \mathrm{~cm}$, or still more, when they are 21 to 24 months old, since specimens over $128 \mathrm{~cm}$ have been caught only in the open sea,outside the lagoon region. Bigelow \& Schroeder (1948, p. 341) estimated that young leucas, with $924 \mathrm{~mm}$, should be one year old, yet clark \& Schmidt (1965, p. 10) believe that in Florida, one year old specimens can reach larger sizes than that mentioned, since in that region a specimen of $88 \mathrm{~cm}$ was caught which should be on $1 y$ a few months old. TABLE II - Size of embryos (+) and young of C. Zeueas collected monthly
in the lagoon region of Cananéia

\begin{tabular}{ccccccccccccccc}
\hline $\begin{array}{c}\text { Size } \\
(\mathrm{cm})\end{array}$ & NOV & DEC & JAN & FEB & MAR & APR & MAY & JUN & JUL & AUG & SEP & OCT & Tota1 \\
\hline 70 & 1 & - & - & - & - & - & - & - & - & - & - & - & 1 \\
- & - & - & - & 1 & - & - & - & - & - & - & - & - & 1 \\
74 & - & - & - & 2 & - & - & - & - & - & - & - & - & 2 \\
- & - & - & +1 & - & - & - & - & - & - & - & - & - & 1 \\
78 & 2 & - & +2 & 1 & - & - & - & - & - & - & - & - & 5 \\
- & 1 & 1 & +2 & 1 & - & - & - & - & - & - & - & - & 5 \\
82 & 1 & 2 & +5 & 2 & - & - & - & - & - & - & - & - & 10 \\
- & - & 1 & 2 & 1 & - & - & - & - & - & - & - & - & 4 \\
86 & - & - & 1 & 2 & - & - & 1 & - & - & - & - & - & 4 \\
- & - & - & - & - & 1 & - & 1 & - & - & - & - & - & 2 \\
90 & - & - & - & 1 & 1 & - & - & - & - & 1 & - & - & 3 \\
- & - & - & - & - & - & - & - & 1 & - & - & - & - & 1 \\
94 & - & - & - & - & 1 & 1 & - & 1 & - & 1 & - & - & 4 \\
- & - & - & - & - & - & - & - & - & 1 & - & 1 & - & 2 \\
98 & 1 & - & - & - & 1 & - & 1 & - & - & - & 3 & 1 & 7 \\
- & - & 1 & - & - & - & 1 & - & 1 & 2 & 1 & 1 & 1 & 8 \\
102 & - & 1 & - & - & - & - & - & - & 1 & - & 2 & 2 & 6 \\
- & 1 & - & - & - & - & - & - & - & - & - & - & - & 1 \\
106 & 2 & - & - & - & - & - & - & - & - & - & 1 & - & 3 \\
- & - & 1 & - & 1 & - & - & - & - & - & - & - & 1 & 3 \\
110 & 1 & - & - & - & - & - & - & - & - & - & - & - & 1 \\
- & 1 & 1 & 1 & - & - & - & - & - & - & - & - & - & 3 \\
114 & - & - & - & - & - & - & - & - & - & - & - & - & - \\
- & - & - & - & - & - & 1 & - & 1 & - & - & 1 & - & 3 \\
118 & - & - & - & 1 & - & - & - & - & - & - & - & - & 1 \\
- & - & - & 1 & - & - & - & - & - & - & - & - & - & 1 \\
122 & - & - & - & - & - & - & - & - & - & 1 & - & 1 & 2 \\
- & 1 & - & - & - & - & 1 & - & - & - & - & - & - & 2 \\
126 & - & - & - & - & - & - & - & 1 & - & - & 1 & - & 2 \\
\hline & & & & & & & & & & & & & \\
\hline
\end{tabular}

Consequent1y the interpretation of the data gathered in Cananéia does not contradict the results of previous studies, as the observed variation in growth rate may be attributed to the lack of size uniformity of the young at birth, and to the diversity of the ecological conditions in the different nursery areas of the species.

Springer's observations (1960, p. 14, 33; 1963, p. 110) on the feeding inhibition shown by Bull shark females in the nursery grounds in the delta of the Mississippi, at the time of, or during a short period after releasing their young,has not been confirmed in relation to the three females examined in this study (Table I). In the lagoon region of Cananéia, adult females occur ex- 
clusively during the short period of parturition and, in the present case, the last of the females examined had given birth recently, as evidenced by the conditions of its genital apparatus, the other two being caught shortly before bringing forth their young, as recognized by the young's size. However all females, in spite of being on the nursery ground, did not show any signs of feeding inhibition, as evidenced by their stomach contents and the fact that they were caught by long line gear.

The following considerations refer to the question recently arisen as to the coexistence of two distinct forms, both under the name of C. Zeucas, in view of the present population.

Due to diversities found in some of the characters of the Eastern SouthAfrican Bul1 sharks, the revaluation (D'Aubrey, 1964, p. 40; 1965, p. 22; Steffens \& D'Aubrey, 1967, p. 9-15) of the species Carcharhinus amboinensis Müller \& Henle, 1841), which until then had been considered as a synonym of C. Zeucas, was suggested.

To justify the separation of $C$. amboinensis the following non-coincident taxonomic characters were pointed out - a smaller number of the pre-caudal vertebrae (95) and teeth (formula: 12-1-12/11-1-11) and a larger proportional difference between the heights of the first and second dorsal fins - a ratio exceeding 3.5 .

If these characters are to be taken into account then the shark of Swartkops River (South-East Africa) described by Smith (1952, p.859) as being Carcharhinus zambezensis (Peters) should also be included in the form amboinensis.

The smaller number of teeth was already observed by Fourmanoir (1963,p.58) in Bull sharks caught in Madagascar waters, which had the same dental formula and were, therefore, distinguished accordingly as belonging to the malgache variety.

More recently the occurrence of that form was reported in the Eastern At lantic, Nigerian coast (Kreft 1968, p.38) and this finding suggest the possibility of the presence of amboinensis also in the Western Atlantic, which assumption met with the approval of some specialists (personal communications: Drs. J. Garrick, Th. Thoŗson and J. D'Aubrey). This last finding was greatly stimulating for carrying out the examination of the material from Cananéia also from the said point of view.

The data referring to the two non-coincident meristic characters do match perfectly with those of leucas, notwithstanding the finding, in 10 specimens examined in the preceding period, from 1962 to 1965 (Sadowsky, 1967,p.82), of numbers of pre-caudal vertebrae ranging from 101 to 109 . These are intermediate between the two forms in question, without, however, presenting the other characters attributed to amboinensis.

The proportion between the heights of the dorsal fins is recorded for young specimens, from 2.3 to 2.8 , and for adults, from 2.9 to 3.1 . Al1 these figures 
are fairly smaller than the ratio 3.5 given as characteristic of amboinensis and, on the other hand, very similar to those recorded in Florida (Clark \& Schmidt, 1965, p.69) for C. Zeucas. To sum up it is possible to ascertain that the Bull sharks of Cananéia do not show any characters that could put in question their taxonomic position in the present.

The meat of this species is used for human consumption and obtains a good price at the local market. In the region under study there are no records concerning any attacks to human beings by sharks of this species.

\section{RE S UMO}

Noventa e um espécimes jovens e 3 fêmeas adultas de "cação cabeça chata" capturados na região lagunar de Cananéia foram examinados, constatando-se a fórmula dental $27 / 25$ e número de vértebras pré-caudais entre 109 e 115. Verificouse que as proporções entre a $1 \mathrm{a}$. nadadeira dorsal e a $2 \mathrm{a}$. foram de 2.3 e 2.8 para os jovens e de 2.9 até 3.1 para os adultos.Ficou assim confirmado que a forma estudada pertence a $C$. Zeucas. E comum a ocorrência de jovens dentro da região estudada, no entanto, quanto aos adultos, as fêmeas só são encontradas durante o período de parição, i.é, de novembro a fevereiro. Constatou-se que o nümero de embriões nas ninhadas foi de 7 a 9 e seus tamanhos oscilaram entre 768-812 mm. O comprimento do menor jovem 1 ivre encontrado foi de $697 \mathrm{~mm}$, sendo que jovens de presumivelmente 9 a 12 meses têm de 98 a 112 cm; entre 21 e 24 meses alcançam 124 a $128 \mathrm{~cm}$,ou seja,os tamanhos que apresentam quando emigram para mar aberto. Não ficou confirmado o fenômeno da inibição alimentar nas fêmeas capturadas, jā observado em genetrizes da mesma espécie durante o período de parição no delta do Mississippi. o conteúdo estomacal apresentou, por ordem decrescente de abundância: Arius spixii (13); ChZoroscombrus chrysurus (7); A. grandicassus (6); A. barbus (4); Felichtys marinus (3); Genidens genidens (2); Chanophorus tajacica (2); Carcharhinus porosus (2); Conodon nobilis, Caranx crysos, scomberomorus maculatus, Sphyrna tiburo, Rhinoptera brasiliensis, Dasyatis americana, Diapterus rhombeus (1), além de cerca de $25 / 30$ exemplares de Carinectes sp.

\section{RE FERENCES}

BACKUS, R. H., SPRINGER, S. \& ARNOLD Jr., E. L. 1956. A contribution to the natural history of the white-tip shark, Pterolamiops Zongimanus (Poey). Deep Sea Res., vo1. 3, no. 3, p. 178-188.

BARCELLOS, B.N. 1962. Nomes comuns dos peixes da costa do Rio Grande do Sul e seus correspondentes em sistemätica. Bolm Inst. Cienc. nat., no. 15,p. 7-20.

BAUGHMAN, J. \& SPRINGER, S. 1950. Biological and economic notes on the sharks of the Gulf of Mexico, with special reference to those of Texas, and with a key for their identification. Am. Mid1.Nat., vo1. 44, no. 1, p. 96-152.

BIGELOW, H. \& SCHROEDER, W. 1948. Sharks. In: Fishes of the western North Atlantic. Mem. Sears Found. mar. Res., Part 1, p. 59-576.

Bolm Inst. oceanogr. S Paulo, 20 (2): 71-78, 1971 
CLARK, E. \& SCHMIDT, K. 1965. Sharks of the central Gulf coast of Florida. Bu11. mar. Sc., vo1. 15, no. 1, p. 13-82.

D'AUBREY, J. 1964. Preliminary guide to the sharks found off the east coast of South Africa. Oceanogr. Res. Inst., Invest1 Rep., no. 8, p. 1-95.

1965. Sharks of the family Carcharhinidae of the South West Indian Ocean. Bull. South African Ass. mar. Biol. Res., no. 5, p. 22-26.

FOURMANOIR, P. 1961. Requins de la côte ouest de Madagascar. Mém. Inst. scient. Madagasgar, ser. F, 4, p. 3-81.

1963. Complement et correction concernant les requins de la côte ouest de Madagasgar. Cah. ORSTOM, Océanogr., no. 6, p. 57-58.

1965. Liste complementaire des poissons marins de Nha-Trang. Cah. ORSTOM, Océanogr., no. spécie1, p. 1-114.

GERLACH, S. 1958. Die Mangroveregion tropischer Küsten als Lebensraum. Z. Morph. Ökol. Tiere, vol. 46, p. 636-730.

JAKOBI, H. \& SOUZA, E. A. de 1968. Contribuição ao conhecimento da pesca no Paraná. Bolm Univ. Fed. Paranā, Zool, vol. 2, no. 14, p. 329-358.

KREFFT, G. 1968. Knorpelfische (Chondrichthyes) aus dem tropischem Ostat lantik. Atlantide Rep., vol. 10, p. 33-76.

LEMA, T. de 1963. Resultados ictiológicos da la. campanha oceanogräfica do Museu Rio-Grandense de Ciências Naturais. Iheringia, Zoo1., no.30, p.1-56.

SADOWSKY, V. 1967. Selachier aus dem Litoral von São Paulo, Brasilien.Beitr. neotrop. Fauna, vol. 5, no. 2, p. 71-88.

1968. On the measurement of the total length of sharks. Zool. Anz, vol. 181, no. 3/4, p. 197-199.

SCHWARTZ, F. 1961. Additional comments on adult bull sharks, Caroharhinua leucas (Mülier \& Henle), from Chesapeake Bay, Maryland. Chesapeake Sci., vol. 1 , no. 1, p. 68-71.

SMITH, J. 1952. Carcharhinus zambezensis Peters, 1852, with notes on other chondrichthyan fishes. Ann. Mag. nat. Hist,, vol, 12, no, 5, p, 837-863.

SPRINGER, S. 1940. The sex ratio and seasonal distribution of ome florida sharks. Copeia, no. 3, p. 188-194.

1960. Natural history of the sandbar shark, Eulamia milberti, Fishery Bul1. Fish Wildl. Serv. U.S., vol. 61 , no. 178, p. 1-38.

1963. Field observations on large sharks of the Florida = Caribban region. In: GILBERT, P.W. ed.- Sharks and survival. Boston, Heath Co., p. 95-113.

\& GARRICK, J. 1964. A survey of vertebral numbers in sharki, Proe, U.S. natn Mus., vol. 116 , p. 73-96.

STEFFENS, F. \& D'AUBREY, J, 1967. Regression analysis a an ald to shark taxonomy. Oceanogr, Res. Inst. Invest 1 Rep, no. $18, p, 3=16$.

THORSON, T., WATSON, D. \& COWAN, C. 1966. The satatus of the freahater shark of Lake Nicaragua. Copeia, no. 3, p. 385-402.

, COWAN, C. \& WATSON, D. 1966. Sharks and sawfish in the Lake Iaabal= Rio Dulce system, Guatemala. Copeia, no. 3, p. 620-622.

XIMENEZ, I. 1962. Notas sobre elasmobranquios. Cuadro sistematico y sinonimico provisional de los selaceos de la costa uruguaya. Rvta. Inst. Invest. pesq., vol. 1 , no. 1 , p. 35-44. 